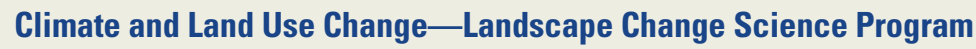

\title{
Mapping, Monitoring, and Modeling Western Gateway Community Landscape Dynamics
}

\section{Pressures Affecting Federal Lands}

Federal public lands in the western United States are becoming increasingly surrounded by Gateway Communities.

These communities are undergoing landscape change due to population growth, economic growth, and the resulting land-use development.

Socioeconomic, demographic, and land-use changes in Gateway Communities are often perceived as threats to Federal land resources, natural amenities, cultural resources, and recreational opportunities.

However, land-surface disturbances on Federal public lands, such as conventional and alternative energy development (which impact surrounding Gateway Communities), are also environmental and societal issues that Federal land and adjacent regional community planners need to consider in their long-range land-use planning.

\section{Gateway Community Definition}

According to the United States House of Representatives Bill 585 (U.S. House of Representatives, 2005), Gateway Communities are those communities that abut or are in close proximity to Federal lands. These communities serve as an entry point for visitors to Federal lands, since they are in close proximity to natural protected lands and function as portals to public use of these Federal lands.

Gateway Communities provide necessary services for visitors to the Federal public lands and to the employees of Federal land-management agencies. These communities generally have a smaller population base and yet are "hotspots" that can experience rapid population and economic growth.

Research by the U.S. Department of Agriculture (USDA) Economic Research Service (Cromartie, 2009) projected that non-metropolitan counties were likely to experience the greatest surge in migration of the Baby Boom generation from 2000 to 2020 . The future preference towards more rural, isolated communities with natural amenities (fig. 1) and recreational opportunities influenced U.S. Geological Survey (USGS) researchers to focus the

Figure 1. U.S. Department of AgricultureEconomic Research Service natural amenities index ranking by county (McGranahan, 1999) for the western United States vintage 1993.

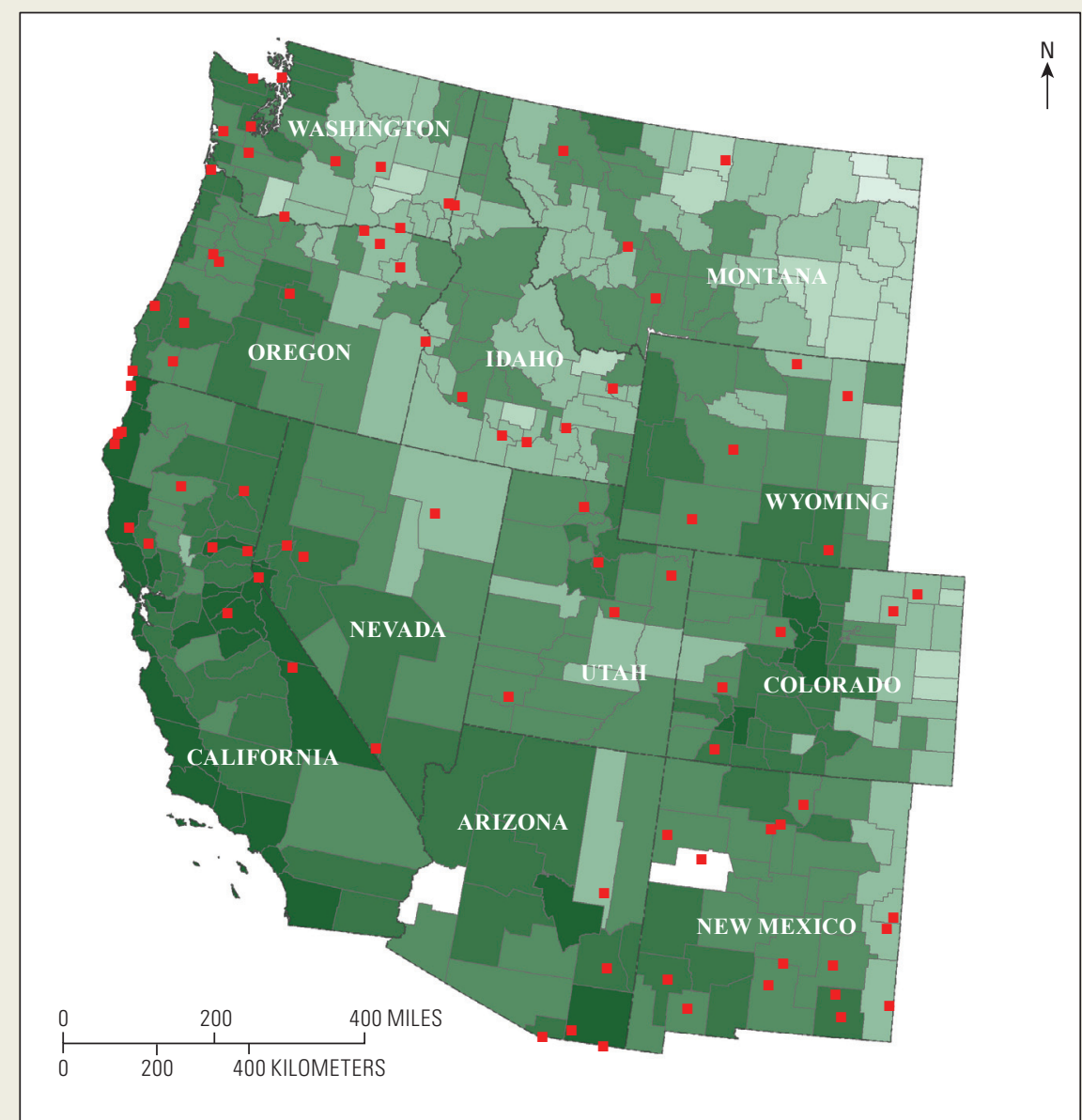

\begin{tabular}{|l|}
\hline \multicolumn{1}{|c|}{ Natural Amenity Parameters } \\
\hline Land Surface Form Topography Codes \\
\hline 1993 Rural-Urban Continuum Codes \\
\hline 1993 Urban Influence Codes \\
\hline Mean Temperature for January 1941-1970 \\
\hline Mean Hourly Sunlight for January 1941-1970 \\
\hline Mean Temperature for July 1941-1970 \\
\hline Mean Relative Humidity for July 1941-1970 \\
\hline \% Water Area (Natural Log) \\
\hline
\end{tabular}

\section{EXPLANATION}

Composite amenity index ranking

7 = over 3

$6=2$ to 3

$5=1$ to 2

$4=0$ to 1

$3=0$ to -1

- Standard deviations from the mean

$2=-2$ to -1

$1=$ over -3 
investigation's research on Micropolitan Statistical Areas as Gateway Community study sites. These micropolitan communities; as defined by the U.S. Census Bureau, have a population base of between 10,000 and 50,000 residents and must have at least one urban cluster that has a population of 10,000 .

\section{Geographic Research Objectives}

Public Federal lands managed by the Bureau of Land Management (BLM), Bureau of Reclamation (BOR), U.S. Forest Service (USFS), U.S. Fish and Wildlife Service (USFWS), and National Park Service (NPS) are geographically concentrated in the 11 western States of the United States (fig. 2). According to the H.R. Bill 585 (Gateway Communities Cooperation Act), these protected recreational areas attract Gateway Community visitors and future residents due to the close proximity of both natural and cultural amenities.

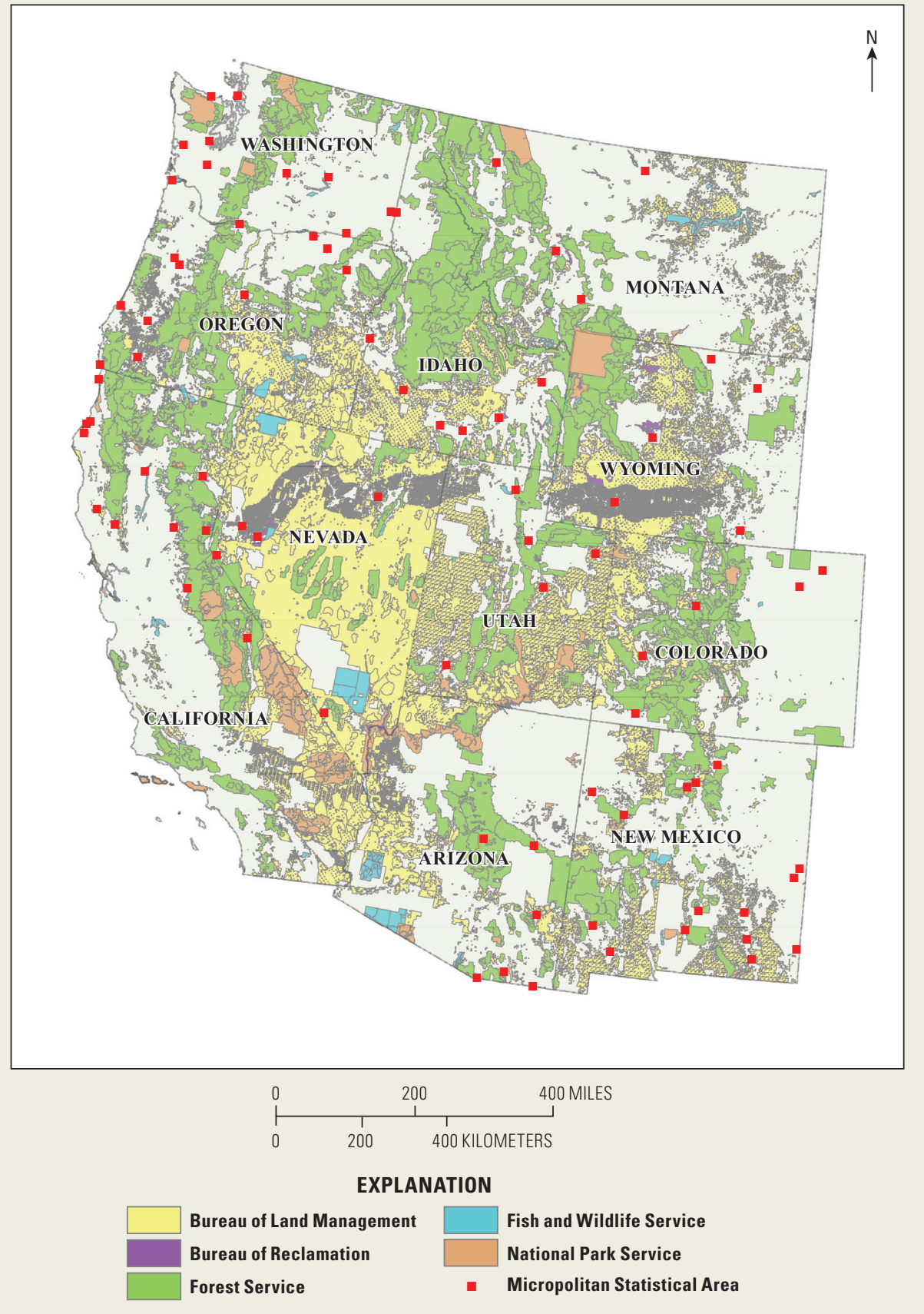

Figure 2. Federal public lands in the Western United States for the Bureau of Land Management, U.S. Bureau of Reclamation, U.S. Forest Service, U.S. Fish and Wildlife Service, and National Park Service.
Gateway Communities will be selected as study sites for monitoring urbanization intensity and density, urban encroachment on adjacent Federal lands, and public land recreational demands (based on an inventory of western United States Federal lands within a specific buffer distance), population growth rates, and economic strength rankings for western U.S. Micropolitan Statistical Areas.

\section{Research Strategy and Approach}

Since Gateway Communities often experience rapid population and economic growth, the USGS derived 1 -year (yr), 3-yr, and 5-yr population growth rates based on 2000-2009 Census Bureau Population Estimates (U.S. Census Bureau, 2010) for all of the Micropolitan Statistical Areas in the 11 western states.

To factor economic growth as a parameter into Western U.S. Gateway Community study site selection, the USGS obtained the 2004-2010 Economic Strength Rankings calculated by the Policom Corporation (Fruth, 2010) for all U.S. Micropolitan Statistical Areas. Based on the Policom data, the USGS derived 1-yr, 3-yr, and 5-yr average economic strength rankings for each of the Western U.S. Micropolitan Statistical Areas.

A standardized timeframe of 2004-2008 for the Overall Combined Population Growth-Economic Strength Ranking was used to account for the national housing boom from 2000 to 2006 as well as the housing foreclosure crisis between 2006 and 2009.

Based on the 2004-2008 Overall Ranking, the top 10 Micropolitan Statistical Areas in the western United States (fig. 3) were selected as potential Gateway Community study sites for monitoring urbanization intensity and recreational demand.

In order to identify which Federal land management unit jurisdictions are in close proximity to each of the Top 10 Micropolitan Statistical Areas, the USGS inventoried Federal public lands within specific travel distances (fig. 4). The objective was to characterize the "Sphere of Influence" or commuting distance that residents and visitors of a Gateway Community would 


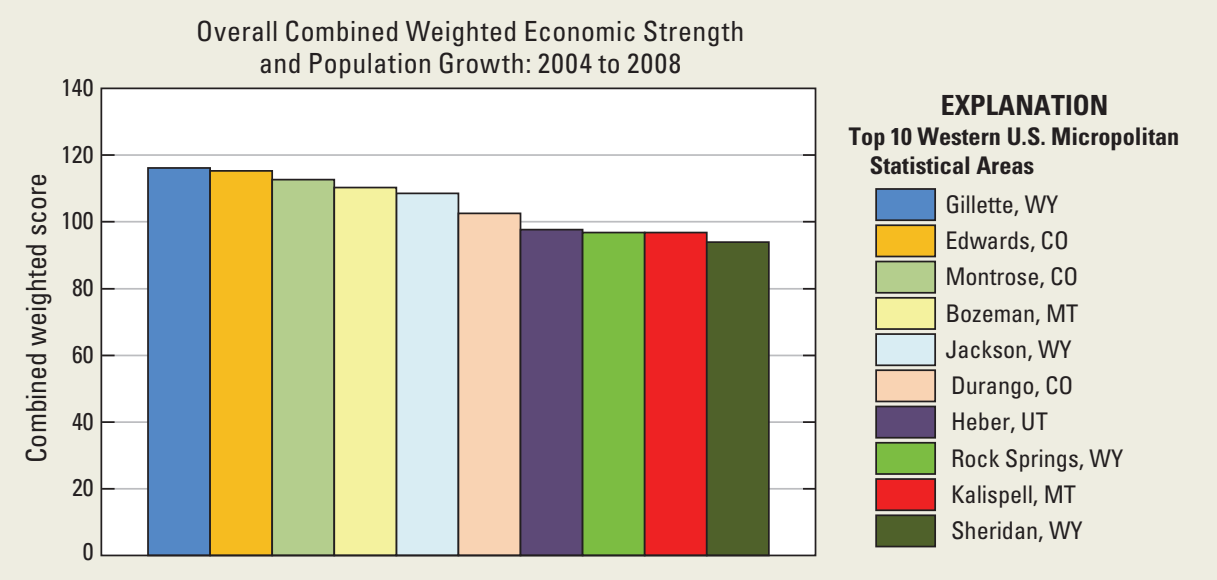

Figure 3. Overall ranking of top 10 western U.S. Micropolitan Statistical Areas for economic strength and population growth from 2004-2008. will be based on metrics developed by the Lincoln Institute of Land-Use Policy's Atlas of Urban Expansion research.

To model future public land recreational demand in Gateway Communities and assess potential impacts on adjacent Federal lands, metrics will be derived based on the USFS National Visitor Use Monitoring (NVUM) analysis. The NVUM research will serve as a socioeconomic and demographic profile template for modeling recreational demand for other Federal public lands adjacent to western United States Gateway Communities. drive in order to recreationally use the Federal public lands adjacent to these communities.

The travel distances, used as the commuting radius to buffer the "Sphere of Influence" of a Gateway Community, were 10 miles (mi), $25 \mathrm{mi}, 50 \mathrm{mi}$, $75 \mathrm{mi}$, and $100 \mathrm{mi}$. The travel distances were mileage values established previously by the BLM in analyzing the proximity of public lands under their land-management authority to population-growth areas. The preferred travel distance of $25 \mathrm{mi}$ was selected for the "Sphere of Influence" of a Gateway Community study site. The entire landsurface area covered by the study area is approximately equal to a large landscapelevel framework, such as a BLM resource-management planning area used for managing Federal public lands.

\section{Gateway Community Research Products}

To map temporal landscape dynamics, within a 25-mi buffer radius of a Gateway Community study area, the USGS will construct a Public Lands Atlas of Changing Environments (PLACE) geodatabase for urbanization intensity and Federal land urban encroachment analysis. Available county-level land parcel data (fig. 5) and the Environmental Protection Agency Office of Smart Growth land-use development classification standards will be used to map the Gateway Community human environment.

Monitoring Gateway Community urban spatial structure, human environment density, and landscape fragmentation

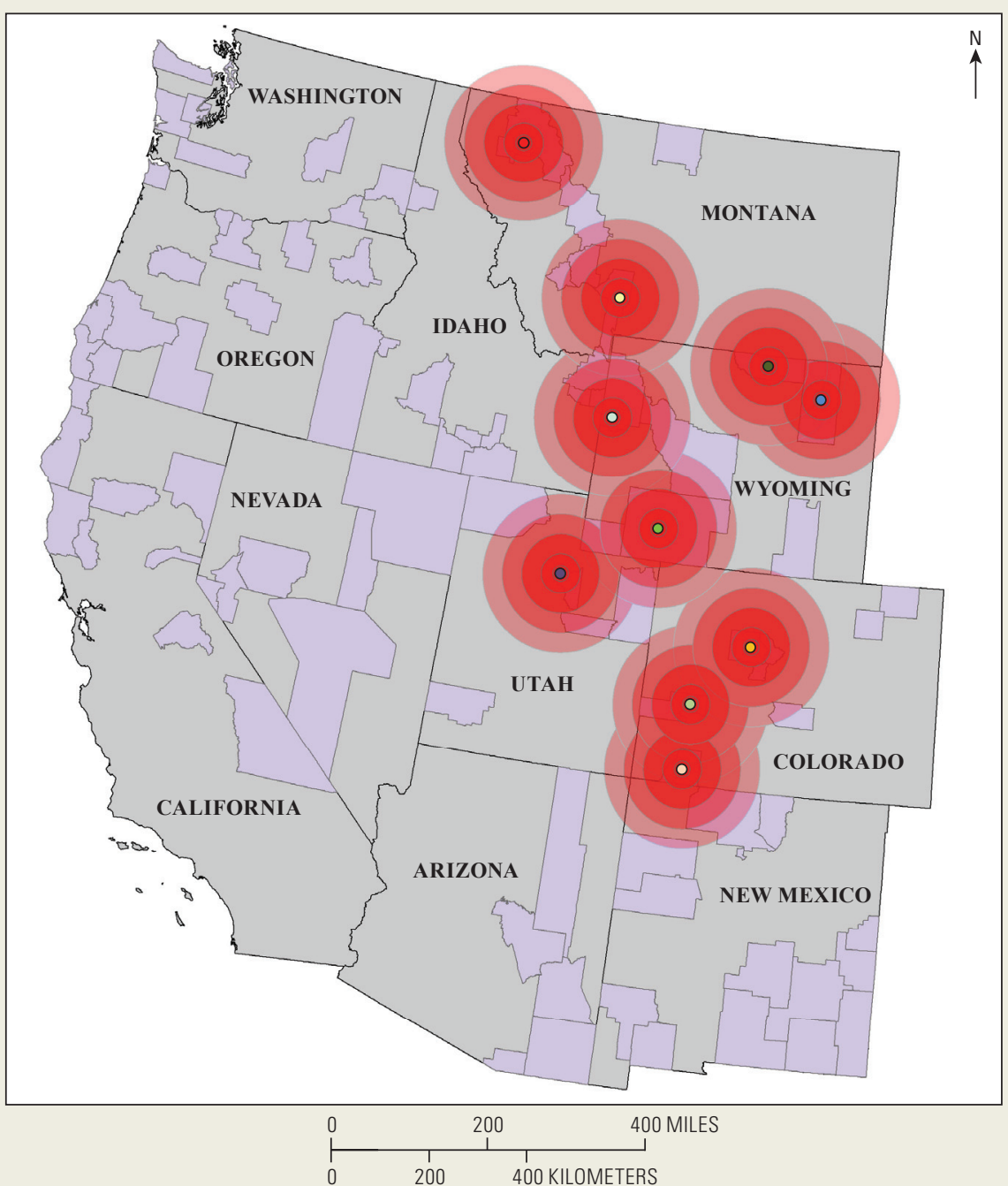

\section{EXPLANATION}

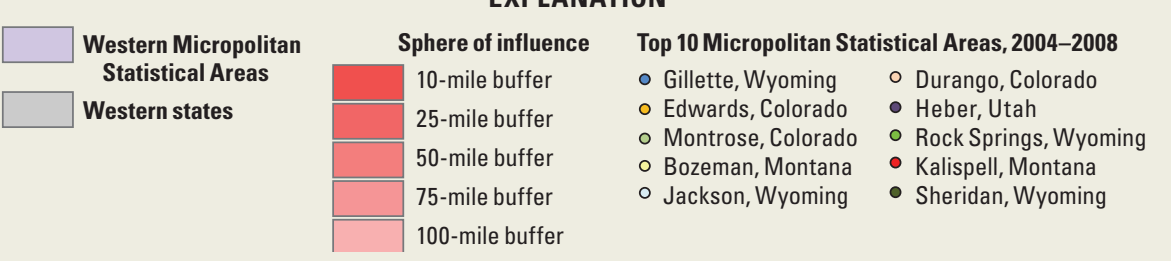

Figure 4. "Spheres of Influence" for the Overall Weighted Top 10 Western U.S. Micropolitan Statistical Areas using predefined buffer distances for recreational commuting from Gateway Communities. 

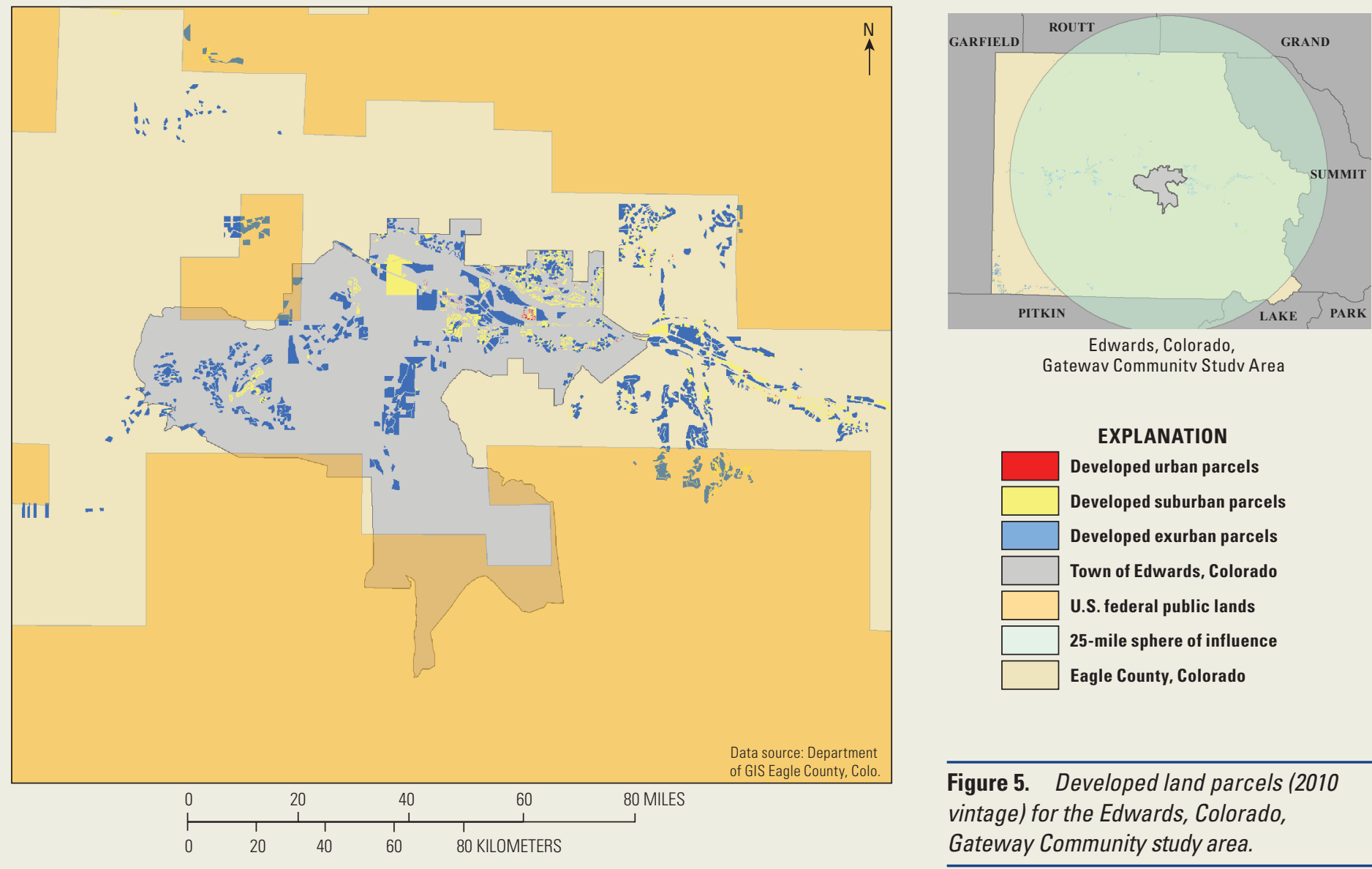

EXPLANATION

Developed urban parcels

Developed suburban parcels

Developed exurban parcels

Town of Edwards, Colorado

U.S. federal public lands

25-mile sphere of influence

Eagle County, Colorado

Figure 5. Developed land parcels 2010 vintage) for the Edwards, Colorado, Gateway Community study area.

\section{References Cited}

Cromartie, J., and Nelson, P., 2009, Baby boom migration and its impact on rural America: U.S. Department of Agriculture, Economic Research Service, Economic Research Report No. 79.

Fruth, W.H., 2010, Economic strength rankings-2010: Palm City, Fla., Policom Corporation, accessed November 29, 2011, at http://www.policom.com/microrank.htm.

McGranahan, D.A., 1999, Natural amenities drive rural population change: U.S. Department of Agriculture, Economic Research Service, Food and Rural Economics Division, Agricultural Economic Report No. 781.

U.S. Census Bureau, 2010, Table 1-Annual estimates of the population of metropolitan and micropolitan statistical areas-April 1, 2000 to July 1, 2009 (CBSA-EST2009-01): Washington D.C., U.S. Census Bureau Population Division, accessed November 29, 2011, at http://www.census.gov/popest/data/metro/totals/2009/index.html.

U.S. House of Representatives, 2005, Gateway Communities Cooperation Act (H.R. Bill 585): U.S. Congress, 109th 1st Session, available via U.S. Government Printing Office, accessed November 29, 2011, at http://www.gpo.gov/fdsys/pkg/BILLS-109hr585rfs/ pdf/BILLS-109hr585rfs.pdf.

\section{For More Information}

Contact David J. Hester, USGS-Geosciences and Environmental Change Science Center, dhester@usgs.gov. 